\title{
ANALISIS KESIAPAN PENERAPAN PROCESS MINING PADA SISTEM MANAJEMEN PEMBELAJARAN UNIVERSITAS TELKOM
}

\author{
Angelina Prima Kurniati* ${ }^{* 1}$, Gede Agung Ary Wisudiawan ${ }^{2}$ \\ ${ }^{1,2}$ Universitas Telkom, Bandung \\ Email: ${ }^{1}$ angelina@telkomuniversity.ac.id, ${ }^{2}$ degunk@telkomuniversity.ac.id \\ "Penulis Korespondensi
}

(Naskah masuk: 09 Agustus 2020, diterima untuk diterbitkan: 17 November 2021)

\begin{abstract}
Abstrak
Sistem manajemen pembelajaran (Learning Management System/LMS) berbasis komputer telah banyak digunakan untuk mengelola pembelajaran dalam institusi pendidikan, termasuk universitas. LMS merekam dan mengelola akses pengguna secara otomatis dalam bentuk event log. Data dalam event log tersebut dapat dianalisis untuk mengenali pola penggunaan LMS sebagai pertimbangan pengembangan LMS. Salah satu metode yang dapat diadopsi adalah process mining, yaitu menganalisis data event log berbasis proses. Analisis data berbasis proses ini bertujuan untuk memodelkan proses yang terjadi dan terekam dalam LMS, mengecek kesesuaian pelaksanaan proses dengan prosedur, dan mengusulkan pengembangan proses di masa mendatang. Makalah ini mengeksplorasi kesiapan data penggunaan LMS di Universitas Telkom sebagai subjek penelitian untuk dianalisis dengan pendekatan process mining. Sepanjang pengetahuan kami, belum ada penelitian sebelumnya yang melakukan analisis data berbasis proses pada LMS ini. Kontribusi penelitian ini adalah eksplorasi peluang untuk menganalisis proses pembelajaran dan pengembangan metode pembelajaran berbasis LMS. Analisis kesiapan LMS dilakukan berdasarkan daftar pengecekan komponen yang dibutuhkan dalam process mining. Makalah ini mengikuti tahap-tahap utama dalam Process Mining Process Methodology $\left(\mathrm{PM}^{2}\right)$. Studi kasus yang dieksplorasi adalah proses pembelajaran pada satu mata kuliah dalam satu semester berdasarkan event log yang diekstrak dari LMS. Hasil penelitian ini menunjukkan bahwa analisis data dalam LMS ini dapat digunakan untuk menganalisis performansi pembelajaran di Universitas Telkom dari kelompok pengguna yang berbeda-beda dan dapat dikembangkan untuk menganalisis data pada studi kasus yang lebih besar. Studi kelayakan ini diakhiri dengan diskusi tentang kelayakan LMS untuk dianalisis dengan process mining, evaluasi oleh tim ahli LMS, dan usulan pengembangan LMS di masa mendatang.
\end{abstract}

Kata kunci: analisis kesiapan, process mining, sistem manajemen pembelajaran, LMS, case study

\section{FEASIBILITY STUDY OF PROCESS MINING ON TELKOM UNIVERSITY LEARNING MANAGEMENT SYSTEM}

\begin{abstract}
Computer-based Learning Management Systems (LMS) are commonly used in educational institutions, including universities. An LMS records and manages user access logs in an event log. Data in an event log can be analysed to understand patterns in the LMS usage to support recommendations for improvements. One promising method is process mining, which is a process-based data analytics working on event logs. Process mining aims to discover process models as recorded in the LMS, conformance checking of process execution to the defined procedure, and suggest improvements. This paper explores the feasibility of Telkom University LMS usage data to be analysed using process mining. To the best of our knowledge, there was no previous research doing process-based data analytics on this LMS. This paper contributes to explore opportunities to analyse learning processes and enhance LMS-based learning methods. The feasibility study is based on a data component checklist for process mining. This paper is written following the main stages on the Process Mining Project Methodology (PM2). We explore a case study of the learning process of a course in a semester, based on an event log extracted from the LMS. The results show that data analytics on this LMS can be used to analyse learning process performance in Telkom University, based on different user roles. This feasibility study is concluded with a discussion on the feasibility of the LMS to be analysed using process mining, an evaluation by the representative of the LMS expert team, and a recommendation for improvements.
\end{abstract}

Keywords: feasibility study, process mining, learning management system, LMS, case study 


\section{PENDAHULUAN}

Sistem Manajemen Pembelajaran (Learning Management System/ LMS) adalah sistem berbasis komputer untuk mengelola pembelajaran dalam sebuah institusi (Bogarin, Cerezo and Romero, 2018). Keunggulan LMS dibanding sistem pembelajaran konvensional adalah kemampuannya dalam mengelola materi pembelajaran yang dapat diakses melalui berbagai perangkat, memudahkan pengajar mengelola materi pengajaran, merekam progress dan performansi pelajar, menekan biaya pengembangan materi, mempersingkat waktu belajar, serta integrasi pengalaman antar para pengajar (Zheng et al., 2018). Imu pengetahuan yang berkembang pesat didukung dengan teknologi maju menyebabkan LMS menjadi media yang semakin digemari untuk mendukung proses belajar mengajar di berbagai level pendidikan (Larose et al., 2016). Makalah ini menganalisis LMS yang digunakan di sebuah perguruan tinggi untuk mendukung proses pengajaran yang melibatkan dosen dan mahasiswa di perguruan tinggi tersebut.

Sebagai sebuah sistem informasi berbasis komputer, LMS merekam dan mengelola akses pengguna secara otomatis setiap saat. Setiap kali dosen atau mahasiswa mengakses LMS (event), LMS merekam data tentang akses yang dilakukan dalam log, yang disebut dengan event log. Data yang direkam dapat digunakan untuk menjelaskan waktu (when) dosen maupun mahasiswa (who) melakukan aksi tertentu (what) pada materi atau menu tertentu (where). Event log tersebut dapat dianalisis lebih lanjut untuk mempelajari bagaimana (how) dan mengapa (why) dosen dan mahasiswa berinteraksi dalam pengajaran yang didukung oleh LMS. Dalam makalah ini, analisis tersebut dilakukan dengan pendekatan process mining. Process mining adalah sebuah metode analisis data berorientasi proses yang mengolah event log untuk menjelaskan proses yang terjadi (van der Aalst et al., 2011). Process mining telah diterapkan dalam berbagai bidang, termasuk bidang pendidikan/ pengajaran (Cairns et al., 2015; Trčka, Pechenizkiy and van der Aalst, 2010; Bogarin, Cerezo and Romero, 2018). Agar process mining dapat menganalisis proses secara efektif, event log harus memiliki komponen-komponen data yang sesuai dengan kebutuhan analisis process mining.

Universitas Telkom adalah sebuah perguruan tinggi swasta di Bandung yang meraih predikat Universitas Swasta Terbaik di Indonesia menurut versi DIKTI pada tahun 2019 (Arthasalina, 2019). Salah satu upaya untuk mendukung dan meningkatkan kualitas pengajarannya adalah membangun LMS CeLOE (Center of e-Learning and Open Education) (Universitas Telkom, 2018). LMS CeLOE telah digunakan sejak tahun 2018 untuk mendukung perkuliahan di Universitas Telkom. Makalah ini bertujuan untuk menganalisis kesiapan LMS CeLOE untuk analisis proses pembelajaran dengan metode process mining. Sebagai studi kasus, makalah ini juga dilengkapi dengan contoh implementasi analisis proses pembelajaran mahasiswa pada satu mata kuliah selama satu semester. Kontribusi makalah ini ditujukan untuk Universitas Telkom dan untuk pengembangan ilmu educational process mining secara umum. Bagi Universitas Telkom, analisis data berbasis proses dengan pendekatan process mining ini diharapkan dapat memberikan rekomendasi pengembangan metode pembelajaran. Sedangkan bagian pengembangan ilmu educational process mining secara umum, analisis dalam makalah ini berpeluang untuk diterapkan pada LMS lain untuk pengembangan proses pembelajarannya.

Makalah ini ditulis dengan sistematika sebagai berikut: Bagian 1 merupakan Pendahuluan, Bagian 2 adalah Studi Pustaka, Bagian 3 berisi Metode Penelitian, Bagian 4 menguraikan Hasil dan Pembahasan, serta Bagian 5 menutup makalah ini dengan Kesimpulan.

\section{METODE PENELITIAN}

Metodologi umum dalam penelitian ini adalah Process Mining Project Methodology $\left(\mathrm{PM}^{2}\right.$ ) (van Eck et al., 2015) yang memiliki kelebihan sebagai metodology standar dalam penerapan process mining dalam berbagai bidang. Kelemahan PM2 adalah tidak secara eksplisit mensyaratkan keterlibatan ahli dalam domain masalah. Untuk mengatasinya, penelitian ini mengadopsi Clearpath method (Johnson et al., 2018) yang menekankan keterlibatan ahli dalam setiap tahap penelitian. Metodologi penelitian ini terdiri atas enam tahap, yaitu (1) Perencanaan, (2) Ekstraksi, (3) Pemrosesan data, (4) Mining dan analisis, (5) Evaluasi, dan (6) Implementasi dan dukungan. Fokus dalam penelitian ini adalah pada tahap Perencanaan, yaitu studi kelayakan penerapan process mining pada LMS CeLOE. Tahap ini dapat disetarakan dengan pengecekan kualitas data (Kurniati et al., 2017). Penelitian ini melibatkan tim ahli dari unit pengelola LMS CeLOE untuk memastikan bahwa pertanyaanpertanyaan riset, tahap-tahap yang dilakukan, hingga hasil yang diperoleh telah sesuai dengan kebutuhan pemilik proses. Tahap Ekstraksi, Pemrosesan data, Mining dan analisis, serta Evaluasi dilakukan pada sampel data berukuran kecil sebagai proof-of-concept dari process mining pada LMS CeLOE. Metodologi penelitian tersebut ditunjukkan pada Gambar 1.

Tahap Perencanaan dilakukan dengan mengidentifikasi proses bisnis dan menentukan pertanyaan-pertanyaan riset. Proses bisnis yang dianalisis adalah proses pembelajaran berbasis LMS CeLOE, dengan fokus pada proses belajar mahasiswa dalam satu kelas mata kuliah selama satu semester. Aktivitas yang ditambahkan pada tahap ini adalah identifikasi komponen minimum LMS CeLOE untuk process mining, untuk mengidentifikasi karakteristik dan kualitas data dari proses pembelajaran.

Tahap Ekstraksi dilakukan dengan mengekstrak data terkait prosedur pengajaran yang diterapkan pada LMS CeLOE. Data diekstrak dalam bentuk web 
log yang berisi data akses pengguna yang direkam otomatis oleh LMS CeLOE.

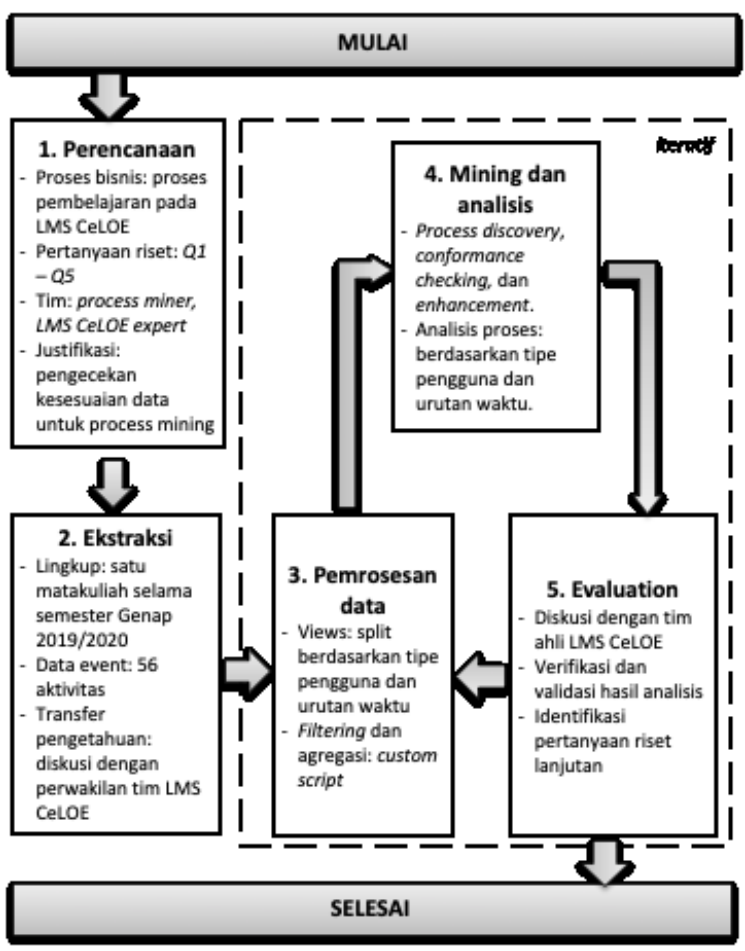

Gambar 1. Metodologi penelitian

Tahap Pemrosesan data dilakukan dengan mengolah data yang diekstrak, dengan menetapkan views, agregasi events, enriching logs dan filtering $\log s$, hingga jadi event log yang siap dianalisis.

Tahap Mining \& analisis mencakup aktivitas process discovery, conformance checking, enhancement, dan analisis proses. Analisis berfokus pada proses belajar mahasiswa, karena dalam satu kelas mata kuliah terdapat beberapa peran yang terlibat, yaitu sekitar 40 mahasiswa, dengan 1-2 dosen dan 1-5 staf admin. Analisis pada proses yang dilakukan dosen dan admin dalam satu kelas mata kuliah akan terlalu subjektif dan tidak representatif terhadap dosen dan staf admin di kelas lain. Tahap Pemrosesan data dan Mining \& analisis dilakukan dengan DISCO, ProM, dan bupaR di R.

Tahap Evaluasi dilakukan melalui diskusi dengan tim ahli LMS CeLOE untuk interpretasi hasil, memastikan hasil analisis telah sesuai ekspektasi, identifikasi pertanyaan riset lanjutan untuk iterasi berikutnya, serta verifikasi dan validasi hasil analisis.

\section{STUDI PUSTAKA}

\subsection{Sistem Manajemen Pembelajaran}

Sistem Manajemen Pembelajaran (Learning Management System/LMS) adalah aplikasi perangkat lunak yang digunakan untuk mengelola administrasi, dokumentasi, pelaporan, dan penyampaian berbagai materi pendidikan maupun program pelatihan (Davis, Carmean and Wagner, 2009). LMS umumnya digunakan di perguruan tinggi dan unit pelatihan di perusahaan. Melalui LMS, pengajar dan pelajar dapat berinteraksi secara langsung (synchronous) maupun tidak langsung (asynchronous) melalui sistem yang terintegrasi. Beberapa fitur yang tersedia dalam LMS secara umum adalah pengelolaan berbagai materi, pengguna, dan peran; ujian online dan kehadiran pelajar; komunikasi antar pelajar maupun antara pelajar dan pengajar; dukungan penyampaian materi dalam berbagai format; serta feedback pengguna. Keuntungan utama LMS adalah interoperability, accessibility, reusability, durability, maintenance ability dan adaptability (Jabr and Al-Omari, 2010).

Proses interaksi antara pengajar dan pelajar di LMS dapat tercatat dalam activity log. Activity log ini berisikan interaksi apa saja yang dilakukan oleh pelajar baik itu membaca materi, mengerjakan quiz, mengerjakan tugas, posting pada suatu forum ataupun sekedar login. Begitu pula pengajar, aktivitas yang direkam ada beberapa macam, seperti upload materi ajar, pembuatan tugas dan quiz, menilai tugas dan quiz, menjawab pertanyaan pada forum ataupun sekedar login. Log aktivitas tersebut dapat digali dengan menggunakan process mining dan dapat digunakan oleh para stakeholder dalam menganalisis proses belajar mengajar. Analisis yang tepat dapat mendukung keputusan dalam monitoring, evaluasi, dan pengembangan proses pembelajaran yang berdasarkan pada data penggunaan LMS.

\subsection{Process Mining}

Process mining (van der Aalst, 2016) adalah sebuah pendekatan manajemen proses untuk analisis proses bisnis berdasarkan event log. Event log dihasilkan secara otomatis dalam sistem informasi berdasarkan akses pengguna secara real-time, sehingga event log dapat dikatakan menggambarkan eksekusi proses real dalam organisasi. Data event log dianalisis dengan process mining untuk mengidentifikasi pola dan tren dalam eksekusi proses. Process mining dapat menjawab pertanyaanpertanyaan tentang proses bisnis, misalnya apa dan mengapa proses bisnis dilakukan di masa lalu, apa yang mungkin terjadi di masa datang, kapan dan mengapa pelaksanaan proses bisnis berbeda dari prosedur, bagaimana mengendalikan proses bisnis, dan bagaimana merancang ulang proses untuk meningkatkan performansinya (van der Aalst, 2016).

Tiga jenis analisis utama dalam process mining adalah process discovery, conformance checking, dan enhancement. Process discovery mengolah event log untuk menghasilkan visualisasi model proses menggunakan algoritma-algoritma process mining, misalnya alpha miner, fuzzy miner, dan heuristics miner. Model proses yang dihasilkan dapat ditampilkan sesuai notasi tertentu, misalnya Petri Net, BPMN, state transition diagram, fuzzy net, dan heuristics net (van der Aalst, 2004). Hasil analisis dalam process mining dapat digunakan untuk mengawasi dan meningkatkan kualitas proses, mengecek kesesuaian dengan prosedur standar, 
mendeteksi aktivitas penghambat dalam proses, dan memprediksi masalah-masalah yang mungkin timbul dalam eksekusi proses.

Proses mining telah digunakan dalam berbagai bidang, termasuk dalam bidang manufaktur (Groger, Niedermann and Mitschang, 2012), kesehatan (Rojas and Munoz-Gama, 2016; Kurniati et al., 2016), dan pendidikan (Bogarin, Cerezo and Romero, 2018; Aisa, Kurniati and Wibowo, 2015). Dalam bidang pendidikan, process mining dapat digunakan untuk menganalisis proses pembelajaran, terutama proses pembelajaran yang berbasis komputer dan dikelola dalam Learning Management System (LMS) (Cairns et al., 2015). Sebuah survei pada process mining di bidang pendidikan (Educational Process Mining/ EDM) (Bogarin, Cerezo and Romero, 2018), process mining di bidang pendidikan juga dapat diterapkan dalam curriculum mining, registrasi mahasiswa, pelatihan profesional, computer-supported collaborative learning, dan lain-lain. Survei tersebut juga menjelaskan bahwa konsep EDM berkaitan erat dengan intention mining (IM), sequential pattern mining (SPM), dan graph mining (GM).

\subsection{Kesesuaian Data untuk Process Mining}

Daftar pertanyaan untuk pengecekan kesiapan data untuk analisis dengan process mining (Anne Rozinat, 2020) adalah sebagai berikut:

1. Data terstruktur? Apakah ada kolom dan baris data?

2. Tersedia kolom Case ID, Activity, dan Timestamp? Apakah ada minimal satu kolom yang bisa menjadi identitas kasus, nama aktivitas, dan timestamp?

3. Case ID sama pada lebih dari satu baris? Apakah case ID yang sama bisa muncul di lebih dari satu baris? Jika setiap baris memiliki case ID unik, maka data tidak dapat digunakan atau perlu diubah formatnya.

4. Activity berbeda pada case yang sama? Apakah ada beberapa activity name dalam case ID yang sama? Jika activity sama, data tidak sesuai dan perlu mencari activity di kolom lain.

5. Timestamps berbeda pada case yang sama? Apakah timestamp berubah sesekali dalam sebuah case? Jika timestamp tidak berubah sepanjang waktu, data tidak sesuai dan timestamp tidak dapat digunakan. Jika data terurut, data bisa digunakan tanpa timestamp.

6. Tanggal dan waktu di satu kolom? Apakah tanggal dan waktu (jam/ menit/ detik) disimpan di satu kolom? Jika timestamps lebih dari satu, tiap timestamp perlu ada dalam satu kolom.

7. Data tersimpan di satu file? Jika data tersebar dalam beberapa file (misalnya, karena berasal dari beberapa sistem komputer), dapatkah dikombinasikan menjadi satu file?
8. Berbagai pola timestamp di beberapa kolom? Jika ada beberapa timestamps dengan berbagai pola, apakah terpisah dalam beberapa kolom?

9. Activity names bisa terbaca? Apakah activity names bisa dipahami (bukan sekedar angka atau kode atau nomor transaksi)?

10. Activity names bisa di-generalisasi? Apakah activity yang sama di case yang berbeda memiliki label activity yang sama (bukan freetext yang berbeda setiap saat)?

Sepuluh pertanyaan di atas menjadi dasar dalam mengecek kesiapan data untuk process mining pada LMS CeLOE.

\section{HASIL DAN PEMBAHASAN}

\subsection{Perencanaan dan Justifikasi}

\subsubsection{Analisis pengajaran di CeLOE LMS}

LMS CeLOE adalah aplikasi di Universitas Telkom untuk mendukung metode pengajaran utama berupa tatap muka di kelas. Kelebihan LMS CeLOE adalah mudah di-customize sesuai kebutuhan institusi, sedangkan kekurangannya adalah durasi penerapan yang singkat (dua tahun) mengakibatkan terbatasnya jumlah data yang tersedia. Pada tahun 2020 telah terdaftar 2435 matakuliah yang menggunakan LMS CeLOE sebagai pendukung perkuliahan. Jenis-jenis aktivitas yang didukung oleh CeLOE adalah pendistribusian lecture note dosen, assignment, quiz, forum, external link, dan video pembelajaran. Tahapan umum penggunaan CeLOE adalah sebagai berikut:

1. Dosen pengembang menyusun dan mengembangkan RPS dan konten mata kuliah di CDS (Content Development System). Konten mata kuliah tersebut antara lain dapat berupa materi teks, video, serta soal kuis/ tugas/ ujian.

2. Di awal semester dilakukan proses sinkronisasi antara data dosen, mahasiswa, kelas, dan mata kuliah serta mengambil data mata kuliah yang di kembangkan pada CDS dan dibuka pada semester berjalan.

3. LMS CeLOE membuat beberapa course dari data yang sudah ada tersebut. Setiap kali sebuah course dibuat, dosen dan mahasiswa yang terdaftar ditambahkan pada course dan kelas tertentu.

4. Mahasiswa melakukan proses perkuliahan di LMS saat perkuliahan sudah dibuka pada awal semester hingga akhir semester. Aktivitasaktivitas yang dapat dilakukan mahasiswa selama masa perkuliahan antara lain adalah melihat materi, mengerjakan kuis/ tugas/ ujian, melihat nilai dan progress belajar.

5. Dosen mengamati aktivitas mahasiswa sesuai dengan RPS dan materi yang sudah disusun sebelumnya (proses cetak Berita Acara Perkuliahan, Absensi, dan penilaian). 
Studi kasus yang dibahas dalam makalah ini adalah proses pembelajaran pada satu mata kuliah selama satu semester, dengan fokus utama pada aktivitas mahasiswa dalam proses pembelajaran.

\subsubsection{Identifikasi kesiapan data}

Analisis kesiapan data dilakukan dengan menjawab sepuluh pertanyaan dalam daftar yang disebutkan pada bagian 2.3, seperti ditunjukkan pada Tabel 1.

Tabel 1. Analisis kesiapan data untuk process mining pada LMS

\begin{tabular}{|c|c|c|}
\hline \multicolumn{3}{|r|}{ CeLOE } \\
\hline \# & Pertanyaan & Penjelasan \\
\hline 1 & $\begin{array}{l}\text { Data } \\
\text { terstruktur? }\end{array}$ & $\begin{array}{l}\text { Data yang tersedia berupa web log, yang } \\
\text { dapat diubah ke dalam format tabel } \\
\text { dengan kolom dan baris data. }\end{array}$ \\
\hline 2 & $\begin{array}{l}\text { Tersedia kolom } \\
\text { Case ID, } \\
\text { Activity, dan } \\
\text { Timestamp? }\end{array}$ & $\begin{array}{l}\text { Kolom-kolom berikut telah } \\
\text { teridentifikasi: } \\
\text { - case ID: user full name } \\
\text { - activity name: event name } \\
\text { - timestamp:time }\end{array}$ \\
\hline 3 & $\begin{array}{l}\text { Case ID sama } \\
\text { pada lebih dari } \\
\text { satu baris? }\end{array}$ & $\begin{array}{l}\text { Telah terdapat case } I D \text { yang sama di } \\
\text { lebih dari satu baris, sehingga data dapat } \\
\text { digunakan untuk dianalisis dengan } \\
\text { process mining. }\end{array}$ \\
\hline 4 & $\begin{array}{l}\text { Activity } \\
\text { berbeda pada } \\
\text { case yang } \\
\text { sama? }\end{array}$ & $\begin{array}{l}\text { Ada beberapa activity names dalam case } \\
\text { ID yang sama, sehingga data dapat } \\
\text { digunakan untuk dianalisis dengan } \\
\text { process mining. }\end{array}$ \\
\hline 5 & $\begin{array}{l}\text { Timestamps } \\
\text { berbeda pada } \\
\text { case yang } \\
\text { sama? }\end{array}$ & $\begin{array}{l}\text { Terdapat beberapa timestamps pada case } \\
\text { ID yang sama. Ini menunjukkan bahwa } \\
\text { terdapat history aktivitas-aktivitas pada } \\
\text { sebuah case. }\end{array}$ \\
\hline 6 & $\begin{array}{l}\text { Tanggal dan } \\
\text { waktu di satu } \\
\text { kolom? }\end{array}$ & $\begin{array}{l}\text { Tanggal dan waktu tersimpan dalam } \\
\text { satu kolom, dengan format } \\
\text { (DD/MM/YY, hh:mm). }\end{array}$ \\
\hline 7 & $\begin{array}{l}\text { Data tersimpan } \\
\text { di satu file? }\end{array}$ & $\begin{array}{l}\text { Data tersimpan dalam satu file yang } \\
\text { dapat diunduh dari LMS CeLOE, berupa } \\
\text { file teks .csv. }\end{array}$ \\
\hline 8 & $\begin{array}{l}\text { Berbagai pola } \\
\text { timestamp di } \\
\text { beberapa } \\
\text { kolom? }\end{array}$ & $\begin{array}{l}\text { Hanya terdapat satu pola timestamps } \\
\text { yang menunjukkan kapan aktivitas } \\
\text { dilakukan oleh user, yaitu pola } \\
\text { timestamp yang menunjukkan tanggal, } \\
\text { bulan, tahun, jam, dan menit saat sebuah } \\
\text { aktivitas dilakukan oleh pengguna. }\end{array}$ \\
\hline 9 & $\begin{array}{l}\text { Activity names } \\
\text { bisa terbaca? }\end{array}$ & $\begin{array}{l}\text { Terdapat } 56 \text { activity names sesuai } \\
\text { dengan tahap-tahap penggunaan LMS } \\
\text { oleh pengguna, beberapa diantaranya } \\
\text { adalah: Course viewed, Quiz attempted, } \\
\text { Course module viewed, User graded. }\end{array}$ \\
\hline 10 & $\begin{array}{l}\text { Activity names } \\
\text { bisa di- } \\
\text { generalisasi? }\end{array}$ & $\begin{array}{l}\text { Activity names yang sama di case yang } \\
\text { berbeda telah memiliki activity label } \\
\text { yang sama, sehingga dapat disimpulkan } \\
\text { bahwa activity names dapat } \\
\text { digeneralisasi. }\end{array}$ \\
\hline
\end{tabular}

Secara singkat, LMS CeLOE telah memiliki data yang cukup untuk dianalisis dengan process mining. Komponen-komponen yang dibutuhkan telah tersedia, dengan beberapa catatan untuk mengubah format data awal sesuai dengan kebutuhan dalam process mining. Pada tahap ini, teridentifikasi beberapa kondisi yang berpotensi menjadi masalah dalam analisis dengan process mining, yang perlu didiskusikan dengan tim ahli LMS CeLOE. Beberapa diantaranya adalah tingkat kedalaman timestamp yang hanya hingga menit tanpa detik, serta activity names yang mirip, misalnya Course viewed dengan Course module viewed.

\subsubsection{Perumusan pertanyaan-pertanyaan riset}

Berdasarkan diskusi dengan tim ahli LMS CeLOE, analisis kesiapan data dengan sepuluh (10) pertanyaan pada Tabel 1, dan menurut literatur tentang pertanyaan yang sering muncul dalam analisis proses bisnis, pertanyaan-pertanyaan riset dalam penelitian ini adalah sebagai berikut:

Q1. Apakah LMS CeLOE memiliki data yang cukup untuk dianalisis dengan process mining?

Q2. Bagaimana model proses penggunaan LMS CeLOE secara umum?

Q3. Apa perbedaan model proses LMS CeLOE menurut peran pengguna?

Q4. Apakah ada perbedaan pola penggunaan LMS CeLOE dari waktu ke waktu?

Q5. Apakah hasil process mining LMS CeLOE sesuai dengan kebutuhan pemilik proses?

Pertanyaan riset pertama $(Q 1)$ telah dijawab pada subbab 4.1.2 dengan analisis kesiapan data untuk process mining berdasarkan 10 pertanyaan yang telah ditetapkan. Tiga pertanyaan riset selanjutnya $(Q 2-Q 4)$ dijawab dalam penelitian ini melalui analisis sampel data LMS CeLOE satu mata kuliah selama satu semester. Sampel data ini dipilih dengan mempertimbangkan kelengkapan data (proses pengumpulan tugas, pengerjaan quiz, dan forum diskusi sesuai kebutuhan LMS CeLOE) selama satu semester Genap 2019/2020. Pertanyaan riset terakhir (Q5) dijawab dengan evaluasi hasil oleh pemilik proses, yaitu perwakilan tim ahli LMS CeLOE.

\subsection{Ekstraksi dan pemrosesan data}

Data mentah adalah log akses LMS dari satu matakuliah pada kurun waktu 28 Januari hingga 21 Mei 2020. Event log terdiri atas 43 kasus (cases), 6.171 kejadian (events), 56 aktivitas (activities), dengan durasi kasus median (median case duration) 14,3 minggu, dan rata-rata (mean case duration) 12.73 minggu. Event log tersebut menunjukkan bahwa jumlah pengguna yang mengakses LMS CeLOE mata kuliah ini adalah 43 orang, dengan total akses sebanyak 6.171 kali, yang terdiri atas 56 aktivitas yang berbeda. Median dan rata-rata durasi dapat dibandingkan dengan durasi menunjukkan bahwa pengguna mengakses LMS CeLOE dengan nilai tengah dan rata-rata kurang dari durasi perkuliahan (16 minggu) dalam semester tersebut.

Membangun model proses secara langsung dari event log ini menghasilkan spaghetti model, seperti ditunjukkan pada Gambar 2. Kondisi ini menunjukkan pentingnya analisis lebih lanjut untuk menyederhanakan visualisasi dan meningkatkan pemahaman pola akses pengguna. Dalam penelitian ini, analisis lebih lanjut dilakukan berdasarkan pertanyaan penelitian Q2-Q5. 


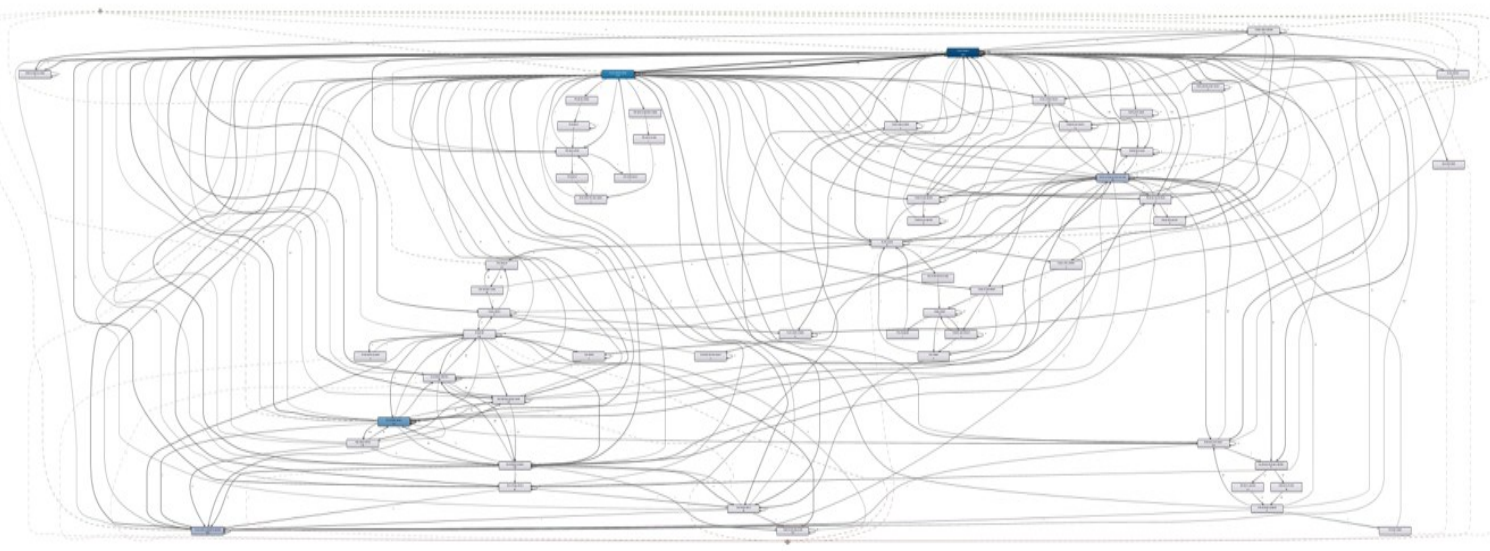

Gambar 2. Model proses seluruh data dalam event log. Model proses ini kompleks dan tidak dapat dipahami secara visual.

Tabel 2 menunjukkan 20 aktivitas yang paling sering muncul dalam dataset LMS CeLOE. Sepuluh aktivitas yang paling sering muncul adalah:

1. Course viewed $(n=1.648 / 26,71 \%)$,

2. Course module viewed $(n=1.271 / 20,6 \%)$,

3. Quiz attempted ( $n=767 / 12,43 \%)$.,

4. Course activity completion updated, $(n=389 /$ $6,3 \%)$,

5. The status of the submission has been viewed ( $n=368 / 5,96 \%)$,

6. Quiz attempt reviewed $(n=250 / 4,05 \%)$,

7. User graded $(n=234 / 3,79 \%)$,

8. Quiz attempt summary viewed $(n=167 / 2,71 \%)$

9. Quiz attempt started $(n=154 / 2,5 \%)$

10. Quiz attempt submitted $(n=154 / 2.5 \%)$

Aktivitas-aktivitas yang paling sering muncul dapat digunakan sebagai filter tambahan untuk menyederhanakan model proses. Misalnya, lima aktivitas yang paling sering muncul (nomor 1-5) mewakili $72 \%$ aktivitas yang paling sering dilakukan oleh para pengguna LMS CeLOE, sedangkan sepuluh aktivitas yang paling sering muncul mewakili 87,55\% aktivitas yang paling sering dilakukan oleh para pengguna LMS CeLOE.

Lima aktivitas yang paling sering dilakukan adalah sebagai berikut. Aktivitas Course viewed mencatat aktivitas pengguna saat melihat deskripsi mata kuliah. Aktivitas Course module viewed mencatat aktivitas pengguna saat melihat detail mata kuliah pada pertemuan tertentu. Aktivitas Quiz attempted menunjukkan saat pengguna mencoba menjawab pertanyaan/ kuis. Ketiga aktivitas tersebut sesuai konfirmasi dari anggota tim ahli menunjukkan tiga aktivitas yang paling sering dilakukan pengguna pada LMS CeLOE. Aktivitas Course activity completion updated mencatat kondisi saat penyelesaian sebuah aktivitas diupdate. Sedangkan aktivitas The status of the submission has been viewed menunjukkan saat pengguna melihat status dari pengumpulan tugas/ kuis.

Tabel 2. Aktivitas yang paling sering dilakukan para pengguna LMS CeLOE

\begin{tabular}{|c|c|c|}
\hline Activity & $\Delta$ Frequency & Relative frequency \\
\hline Course viewed & 1,648 & $26.71 \%$ \\
\hline Course module viewed & 1,271 & $20.6 \%$ \\
\hline Quiz attempt viewed & 767 & $12.43 \%$ \\
\hline Course activity completion updated & 389 & $6.3 \%$ \\
\hline The status of the submission has been viewed. & 368 & $5.96 \%$ \\
\hline Quiz attempt reviewed & 250 & $4.05 \%$ \\
\hline User graded & 234 & $3.79 \%$ \\
\hline Quiz attempt summary viewed & 167 & $2.71 \%$ \\
\hline Quiz attempt started & 154 & $2.5 \%$ \\
\hline Quiz attempt submitted & 154 & $2.5 \%$ \\
\hline Submission form viewed. & 108 & $1.75 \%$ \\
\hline Grade deleted & 73 & $1.18 \%$ \\
\hline A submission has been submitted. & 71 & $1.15 \%$ \\
\hline A file has been uploaded. & 71 & $1.15 \%$ \\
\hline Submission created. & 59 & $0.96 \%$ \\
\hline Role assigned & 39 & $0.63 \%$ \\
\hline User enrolled in course & 39 & $0.63 \%$ \\
\hline User list viewed & 37 & $0.6 \%$ \\
\hline Question manually graded & 36 & $0.58 \%$ \\
\hline Quiz report viewed & 24 & $0.39 \%$ \\
\hline
\end{tabular}




\subsection{Mining dan analisis}

\subsubsection{Model proses umum LMS CeLOE}

Model proses pada Gambar 2 dapat disederhanakan dengan menerapkan filter berdasarkan aktivitas yang paling sering dilakukan para pengguna LMC CeLOE (Tabel 2). Misalnya dengan hanya menampilkan aktivitas yang memiliki frekuensi minimal 20\%. Model proses yang dihasilkan ditunjukkan pada Gambar 3. Model proses ini menunjukkan pola akses utama yang diikuti pengguna, untuk menjawab pertanyaan $Q 2$ (Bagaimana model proses penggunaan LMS CeLOE secara umum?).

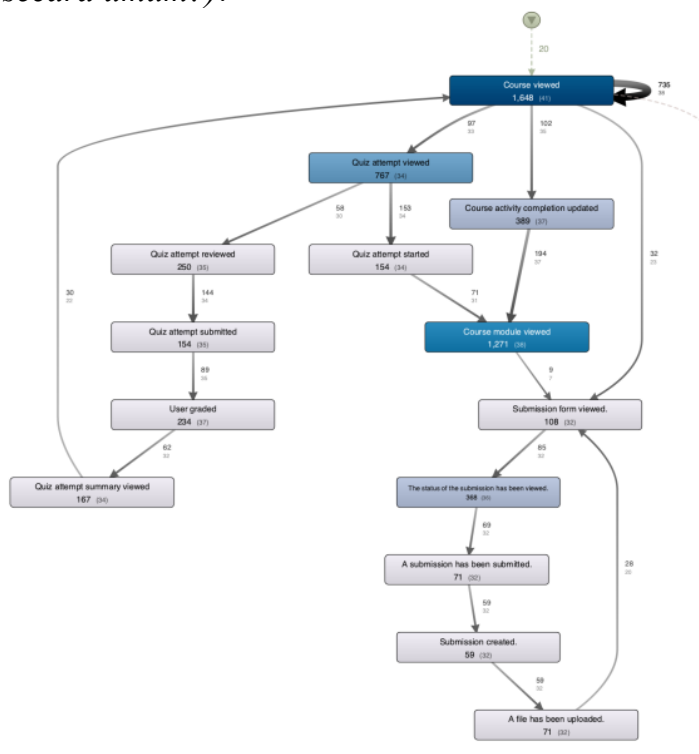

Gambar 3. Model proses yang disederhanakan (20\% aktivitas).

Setiap kotak menunjukkan aktivitas, garis berpanah menunjukkan alur dari satu aktivitas ke aktivitas lainnya dengan angka pada garis menunjukkan jumlah pengguna yang melewati alur tersebut. Jalur ditunjukkan oleh alur dari Mulai (titik dengan segitiga terbalik) hingga Selesai (titik dengan kotak di dalamnya).

Gambar 3 menunjukkan bahwa pengguna umumnya mengakses LMS diawali dan diakhiri dengan melihat halaman mata kuliah (Course viewed/ $n=1.647$ ) berkali-kali hingga akhirnya menyelesaikan kuliah (Course activity completion updated/ $n=389$ ), melihat kuis (Quiz attempt viewed/ $n=767$ ), maupun melihat ringkasan kuis (Quiz attempt summary viewed/ $n=167$ ).

\subsubsection{Model proses berdasarkan peran}

Analisis selanjutnya dilakukan dengan mengelompokkan pengguna berdasarkan perannya. Terdapat tiga peran dalam LMS CeLOE, yaitu dosen, mahasiswa, dan staf administrasi. Pada dataset ini, terdapat 2 staf administrasi, 3 dosen, dan 38 mahasiswa. Model proses dianalisis berdasarkan ketiga peran tersebut dan dibandingkan, untuk menjawab pertanyaan riset $Q 3$ (Apa perbedaan model proses LMS CeLOE menurut peran pengguna?). Model proses mahasiswa akan ditampilkan dan dibahas lebih lanjut, sedangkan model proses staf administrasi dan dosen tidak ditampilkan dalam makalah ini karena hanya menggambarkan proses dari 2-3 orang dan tidak representatif terhadap seluruh staf administrasi dan dosen.

Mahasiswa adalah pengguna utama LMS CeLOE, dengan jumlah 5.795 events (94\% dari total), 38 cases ( $88 \%$ dari total), dan 53 activities (95\% dari total). Model proses mahasiswa ditunjukkan pada Gambar 4.

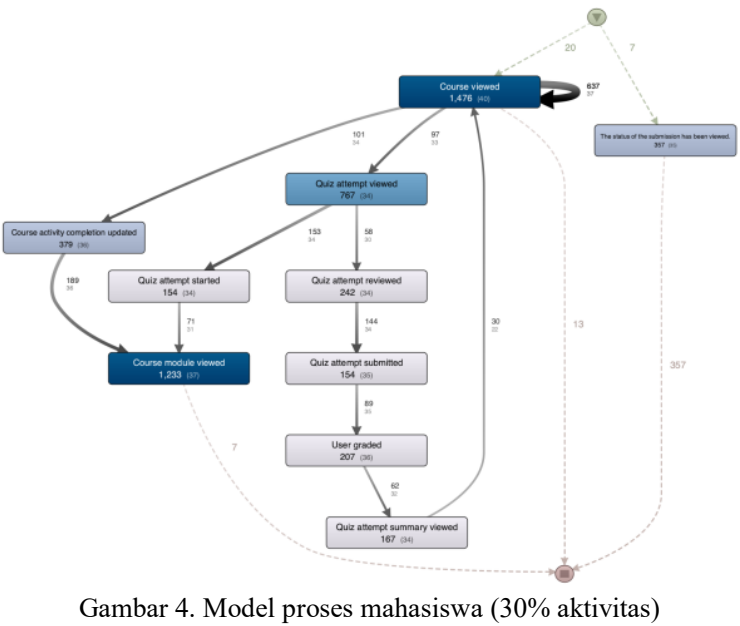

Staf administrasi menggunakan LMS CeLOE untuk mengelola pengguna dan administrasi perkuliahan. Terdapat 11 aktivitas yang dilakukan staf administrasi, meliputi User graded (120/ $54,05 \%)$, Role assigned (37/ 16,67\%), User enrolled in course (37/ 16,67\%), Quiz attempt submitted (7/ $3,15 \%)$, Course updated (5/2,25\%), Course section created (5/ 2,25\%), Item deleted (3/ 1,35\%), Enrolment instance created (3/ 1,35\%), Calendar event created (2/ 0,9\%), Course summary viewed (2/ 0,9\%), dan Course restored (1/ 0,45\%). Model proses yang dihasilkan telah didiskusikan dengan perwakilan tim ahli LMS CeLOE dan dikonfirmasi bahwa model tersebut telah sesuai dengan kondisi sebenarnya. Pada tahap ini juga teridentifikasi beberapa aktivitas yang tidak sesuai dengan peran staf administrasi, misalnya User graded dan Quiz attempt submitted. Perwakilan tim ahli LMS CeLOE menjelaskan bahwa hal ini terjadi karena kelas yang diambil sebagai contoh dalam dataset ini adalah kelas yang diajar oleh salah satu staf administrasi LMS CeLOE. Model proses staf administrasi tidak ditampilkan dalam makalah ini.

Dosen menggunakan LMS CeLOE untuk menyampaikan materi, mengelola kelas, tugas dan nilai. Terdapat 40 aktivitas berbeda yang dilakukan oleh dosen, dengan lima aktivitas yang paling sering muncul adalah Course viewed (174/ 30\%), Grade deleted (73/ 12,59\%), Course module viewed (38/ $6,55 \%)$, Question manually graded (36/ 6,21\%), User graded (27/ 4,66\%), Quiz report viewed (24/4,14\%), Quiz edit page viewed (23/3,97\%), User list viewed 
(20/ 3,45\%), Course module updated (15/ 2,59\%), dan Course module created (14/2,41\%). Berdasarkan hasil diskusi dengan tim ahli LMS CeLOE, tiga akun dosen yang tercatat dalam dataset ini adalah dosen pengajar di kelas ini, dan dua akun dosen dummy. Karena alasan tersebut, model proses dosen tidak ditampilkan dalam makalah ini.

\subsubsection{Model proses berdasarkan waktu}

Analisis model proses diawali dengan menganalisis jumlah pengguna aktif sepanjang waktu. Gambar 5 menunjukkan diagram jumlah pengguna aktif sepanjang waktu.

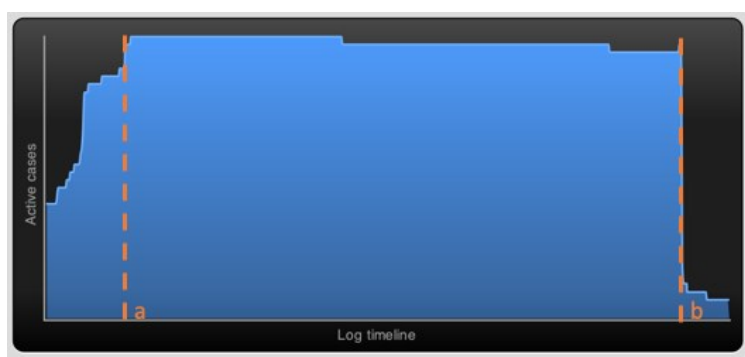

Gambar 5. Diagram jumlah pengguna aktif sepanjang waktu. Garis putus-putus menunjukkan titik waktu (a) 11-02-2020 dan (b) $13-05-2020$.

Pada Gambar 5 ditunjukkan bahwa jumlah pengguna aktif sepanjang waktu mengalami peningkatan sejak 28 Januari hingga 11 Februari 2020 (lihat titik a pada Gambar 5). Jumlah pengguna aktif sejak 10 Februari 2020 (a) hingga 13 Mei 2020 (b) relatif stabil. Sejak 13 Mei 2020 hingga akhir $21 \mathrm{Mei}$ 2020.

Analisis ini dilanjutkan dengan membagi event $\log$ ke dalam sublogs berdasarkan tahap-tahap pembelajaran di dalam semester berjalan, yaitu:

- Pra-UTS 13 Januari - 1 Maret 2020

- UTS 2-11 Maret 2020

- Pra-UAS 12 Maret - 3 Mei 2020

- UAS 4-13 Mei 2020

- $\quad$ Pasca-UAS 14-21 Mei 2020

Ringkasan sublogs yang terbentuk ditunjukkan pada Tabel 3.

Tabel 3. Ringkasan sublogs berdasarkan tahap pembelajaran

\begin{tabular}{cccccc}
\hline Sublog & $\begin{array}{c}\text { Jumlah } \\
\text { Events }\end{array}$ & $\begin{array}{c}\text { Jumlah } \\
\text { Cases }\end{array}$ & $\begin{array}{c}\text { Jumlah } \\
\text { Activities }\end{array}$ & $\begin{array}{c}\text { Median } \\
\text { Durasi } \\
\text { (hari) }\end{array}$ & $\begin{array}{c}\text { Rata-rata } \\
\text { Durasi } \\
\text { (hari) }\end{array}$ \\
\hline Pra-UTS & 2.143 & 41 & 46 & 17 & 16,5 \\
UTS & 322 & 30 & 14 & 1 & 1 \\
Pra-UAS & 2.685 & 38 & 32 & 45 & 37 \\
UAS & 346 & 31 & 17 & 1 & 1 \\
Pasca-UAS & 22 & 4 & 7 & 1 & 1
\end{tabular}

Pada Tabel 3 ditunjukkan bahwa hampir seluruh pengguna mengakses LMS CeLOE selama Pra-UTS hingga UAS, namun hanya 4 pengguna yang mengaksesnya Pasca-UAS. Dari durasi penggunaan, pengguna umumnya mengakses dalam satu hari pada masa UTS, UAS, maupun Pasca UAS. Durasi akses yang lebih panjang adalah pada masa Pra-UTS (ratarata 16,5 hari) dan Pra-UAS (37 hari).

\subsection{Evaluasi}

\subsubsection{Evaluasi dengan 5-fold cross validation}

Evaluasi pertama dilakukan dengan 5-fold cross validation (Cerqueira, Torgo and Mozetic, 2020). Dataset lengkap dibagi ke dalam lima kelompok secara acak dan satu persatu secara iteratif menjadi data uji sedangkan kelompok lainnya menjadi data latih. Pada setiap iterasi, data latih digunakan untuk membangun model proses dan data uji digunakan untuk menguji kualitas model proses tersebut. Evaluasi dilakukan berdasarkan empat ukuran kualitas yang biasa digunakan dalam process mining, yaitu trace fitness, precision, generalisation, dan simplicity (Buijs, van Dongen and van der Aalst, 2012). Hasil dari lima pengujian dalam 5-fold cross validation dirangkum pada Tabel 4.

Tabel 4. Hasil 5-fold cross validation

\begin{tabular}{ccccc}
\hline Data uji & $\mathbf{F}$ & $\mathbf{P}$ & $\mathbf{G}$ & $\mathbf{S}$ \\
\hline 1 & 0,821 & 0,191 & 0,277 & 0,387 \\
2 & 0,840 & 0,192 & 0,284 & 0,387 \\
3 & 0,808 & 0,189 & 0,507 & 0,387 \\
4 & 0,937 & 0,188 & 0,304 & 0,387 \\
5 & 0,934 & 0,192 & 0,278 & 0,387 \\
\hline Rata-rata & 0,868 & 0,186 & 0,330 & 0,387 \\
\hline
\end{tabular}

Tabel 4 menunjukkan hasil 5-fold cross validation berdasarkan bahwa rata-rata trace fitness adalah 0,868 , rata-rata precision adalah 0,186 , ratarata generalisation adalah 0,330 , dan rata-rata simplicity adalah 0,387. Hasil ini menunjukkan bahwa model proses yang dihasilkan dapat menggambarkan perilaku pengguna dalam LMS CeLOE (trace fitness tinggi), namun tidak presisi (presicion rendah), dengan generalisation dan simplicity sedang.

\subsubsection{Evaluasi oleh pakar LMS CeLOE}

Evaluasi oleh perwakilan tim ahli LMS CeLOE dilakukan sepanjang pelaksanaan penelitian, untuk menguji ketepatan setiap tahap penelitian, terutama untuk menjawab pertanyaan riset kelima (Q5. Apakah hasil analisis process mining LMS CeLOE sesuai dengan kebutuhan pemilik proses?). Evaluasi dilakukan dengan mendiskusikan hasil riset dengan perwakilan tim ahli LMS CeLOE.

Secara umum, kelebihan-kelebihan dari penelitian ini adalah sebagai berikut. LMS CeLOE 
memiliki data yang dibutuhkan untuk analisis proses dengan pendekatan process mining. Hal ini ditunjukkan pada hasil pengecekan kesiapan data, seperti ditunjukkan pada Table 1. Contoh kasus yang diangkat dalam tulisan ini cukup sederhana dan mudah dipahami, serta mewakili kondisi riil proses pembelajaran online di satu mata kuliah selama satu semester. Metode dan tools yang digunakan dalam penelitian ini juga merupakan pendekatan yang sederhana dan menggunakan framework yang sudah tersedia sehingga mudah diterapkan di studi kasus lainnya. Dari studi kasus yang diambil juga dapat ditunjukkan bahwa ada perbedaan model proses menurut peran pengguna, serta perbedaan dari waktu ke waktu. Evaluasi dengan 5-fold cross validation menunjukkan bahwa model proses yang dihasilkan memiliki trace fitness yang tinggi, namun precision, generalisation dan simplicity rendah. Ini berarti bahwa proses model dapat menggambarkan seluruh data yang tersimpan dalam LMS, namun ketepatan dalam menggambarkan pola akses masing-masing pengguna masih sangat rendah, sehingga tidak dapat digeneralisasi. Model yang dihasilkan juga kompleks karena tingginya keragaman pola yang ada.

Keterbatasan dari studi kasus yang diambil adalah karena hanya mencakup satu mata kuliah pada satu semester, hanya ada sejumlah kecil dosen dan staf administrasi yang terlibat dalam proses pembelajaran di LMS CeLOE. Pada tahap ekstrasi, teridentifikasi beberapa keterbatasan dalam format dan granularity data. Komponen yang potensial menjadi case-id hanya username, yang berarti bahwa analisis dapat dilakukan untuk menghasilkan model proses tiap pengguna pada satu semester, namun tidak dapat memodelkan proses pada satu kali login/ akses LMS. Peran pengguna juga tidak tercatat di LMS CeLOE. Hal ini dapat diatasi dengan menghubungkannya dengan tabel mahasiswa dan tabel dosen/ pegawai untuk mengenali peran pengguna tersebut dalam LMS CeLOE. Selain itu, timestamp yang tersimpan pada LMS CeLOE adalah hingga jam dan menit, tanpa catatan tentang detik. Potensi persoalan karena keterbatasan ini adalah jika pengguna mengakses lebih dari satu halaman dalam satu menit, urutan aksesnya tidak dapat ditentukan. Pada tahap pemrosesan data, dalam diskusi dengan tim pakar LMS CeLOE teridentifikasi adanya namanama aktivitas yang mirip satu sama lain, misalnya Course viewed dan Course module viewed. Hal ini dapat diperbaiki dengan agregasi, yaitu menggabungkan satu aktivitas dengan aktivitas lainnya yang berkaitan, agar lebih mudah dipahami dalam model proses yang dibangun. Hasil pengujian dengan 5-fold cross validation menunjukkan bahwa tingkat presisi, generalisasi, dan kesederhanaannya rendah. Ini berkaitan dengan studi kasus yang menggambarkan satu kelas mahasiswa dan jumlah pengguna sedikit di tiap fold yang diuji.

\section{KESIMPULAN DAN SARAN}

Kesimpulan yang dapat diambil dari penelitian ini adalah sebagai berikut. (1) Metodologi yang diterapkan dalam penelitian ini, yaitu Process Mining Project Methodology $\left(P M^{2}\right)$, dapat digunakan sebagai metodologi umum untuk proyek-proyek process mining. Data penelitian ini ditunjukkan bahwa metodologi ini juga dapat diterapkan untuk menganalisis kesiapan data untuk implementasi process mining dalam analisis proses. (2) Metode ClearPath sesuai untuk diterapkan dalam process mining, terutama pendekatannya untuk melibatkan tim ahli dari domain masalah untuk menganalisis setiap tahap dalam penelitian. (3) Penelitian ini mengecek kesesuaian data untuk analisis dengan process mining menggunakan daftar pertanyaan yang tersedia dalam website resmi fluxicon. Daftar pertanyaan tersebut terbukti dapat digunakan untuk mengecek ketersediaan dan kesesuaian data di LMS CeLOE. (4) Studi kasus yang dipilih dalam penelitian ini, yaitu proses pembelajaran di satu kelas dari satu matakuliah dalam satu semester, dapat mewakili persoalan yang dihadapi dalam menerapkan process mining pada sebuah sistem manajemen pembelajaran. Keragaman pola akses pengguna menurut peran dan waktu dalam semester dapat ditunjukkan dalam analisis proses. (5) Secara umum dapat disimpulkan bahwa LMS CeLOE memiliki data yang siap dianalisis dengan process mining, dengan beberapa catatan untuk meningkatkan kualitas data dan hasil analisisnya.

Saran pengembangan dan potensi penelitian lebih lanjut adalah sebagai berikut. (1) Metodologi penelitian yang diterapkan dalam penelitian ini dapat diuji pada studi kasus yang lebih besar dan lebih beragam, untuk menjadikannya metode umum yang dapat diterapkan di berbagai kasus lain. (2) LMS CeLOE dapat dianalisis dengan process mining dengan peningkatan kualitas data berupa pemberian login_id, pencatatan peran pengguna (sebagai dosen, mahasiswa, staf, dll), pencatatan waktu akses dalam (jam:menit:detik), serta pembuatan skema agregasi untuk menggambarkan keterkaitan satu aktivitas dengan aktivitas lainnya. (3) Potensi penelitian lanjutan adalah dengan menganalisis proses pembelajaran dari semua kelas dalam satu mata kuliah, seluruh mata kuliah dalam satu semester, dan satu matakuliah dalam beberapa semester. Hal ini dilakukan untuk mengenali pola pembelajaran di berbagai kelas, dalam satu semester yang sama maupun pada semester-semester yang berbeda.

\section{ACKNOWLEDGMENT}

Penulis menyampaikan terima kasih pada Universitas Telkom, terutama Unit Pelayanan CeLOE, atas ijin dan data yang diberikan untuk dianalisis dalam penelitian ini. Penulis kedua adalah anggota tim pengembang LMS CeLOE. 


\section{DAFTAR PUSTAKA}

VAN DER AALST, W.M.P., 2004. Workflow mining: Discovering process models from event logs. IEEE Transactions on Knowledge and Data Engineering, 16(9), pp.1128-1142.

VAN DER AALST, W.M.P., 2016. Process Mining: Data Science in Action. 2nd ed. Springer-Verlag Berlin Heidelberg.

VAN DER AALST, W.M.P., Adriansyah, A., Medeiros, A.K.A. De, Arcieri, F. and et al., 2011. Process Mining Manifesto. Business Process Management Workshops, 99, pp.169-194.

AISA, V., KURNIATI, A.P. and WIBOWO, Y.F.A., 2015. Evaluation of the online assessment test using process mining (Case Study: Intensive English Center). In: 2015 3rd International Conference on Information and Communication Technology, ICoICT 2015. pp.472-477.

ARTHASALINA, D.S., 2019. 10 Perguruan Tinggi Swasta Terbaik Tahun 2019 Versi Ristekdikti. IDN Times. [online] Available at: $<$ https://www.idntimes.com/life/education/dianarthasalina/perguruan-tinggi-swasta-terbaiktahun-20192020-versi-ristekdikti>.

BOGARIN, A., CEREZO, R. and ROMERO, C., 2018. A survey on educational process mining. Wiley Interdisciplinary Reviews: Data Mining and Knowledge Discovery, [online] 8(1), p.e1230. Available at: $\quad<$ http://doi.wiley.com/ 10.1002/widm.1230> [Accessed 9 Jun. 2020].

BUIJS, J.C.A.M., VAN DONGEN, B.F. and VAN DER AALST, W.M.P., 2012. On the role of fitness, precision, generalization and simplicity in process discovery. In: H. Springer, Berlin, ed. OTM Confederated International Conferences. pp.305-322.

CAIRNS, A.H., GUENI, B., FHIMA, M., CAIRNS, A., et al. 2015. Process Mining in the Education Domain. International Journal on Advances in Intelligent Systems, 08(1 \& 2), pp.219-232.

CERQUEIRA, V., TORGO, L. and MOZETIC, I., 2020. Evaluating time series forecasting models: an empirical study on performance estimation methods. Machine Learning, pp.1-28.

DAVIS, B., CARMEAN, C. and WAGNER, E., 2009. The Evolution of the LMS: From Management to Learning. The ELearning Guild Research, p.24.

VAN ECK, M.L., LU, X., LEEMANS, S.J. and VAN DER AALST W.M.P., 2015. PM2: A process mining project methodology. In: International Conference on Advanced Information Systems Engineering. pp.297-313.

GROGER, C., NIEDERMANN, F. and
MITSCHANG, B., 2012. Data Mining-driven Manufacturing Process Optimization - Google Scholar. [online] the World Congress on Engineering. Available at: $<$ https://pdfs.semanticscholar.org/a5a8/82eab34d 7d3fe39929044adeadf09a9e5a83.pdf $>$ [Accessed 9 Jun. 2020].

JABR, M.A. and AL-OMARI, H.K., 2010. Design and implementation of E-learning management system using service oriented architecture. World Academy of Science, Engineering and Technology, 64(March), pp.59-64.

JOHNSON, O.A., DHAFARI, T.B.A., KURNIATI, A. and ROJAS, E., 2018. The ClearPath Method for Care Pathway Process Mining and Simulation. In: Lecture Notes in Business Information Processing. pp.1-12.

KURNIATI, A.P., JOHNSON, O., HOGG, D. and HALL, G., 2016. Process Mining in Oncology: a Literature Review. In: The 6th ICICM, IEEE. Hertfordshire.

KURNIATI, A.P., ROJAS E., HOGG, D. and JOHNSON, O., 2017. The assessment of data quality issues for process mining in healthcare using MIMIC-III , a publicly available e-health record database. (2).

LAROSE, D.T., LAROSE, C.D., DZIUDA, D.M., HAMEL, L., MARKOV, Z. and BILISOLY, R., 2016. Data Mining and Learning Analytics: Applications in Educational Research. Hoboken, New Jersey: John Wiley \& Sons.

ROJAS, E. and MUNOZ-GAMA, J., 2016. Process mining in healthcare: A literature review. Journal of biomedical informatics, 61, pp.224-236.

TRCKA, N., PECHENIZKIY M. and VAN DER AALST, W.M.P., 2010. Process mining from educational data. Handbook of Educational Data Mining, pp.123-142.

UNIVERSITAS TELKOM. 2018. LMS CeLOE Universitas Telkom. [online] Available at: $<$ https://ms.telkomuniversity.ac.id/>.

ZHENG, Y., WANG, J., DOLL, W., DENG, X. and WILLIAMS, M., 2018. The impact of organisational support, technical support, and self-efficacy on faculty perceived benefits of using learning management system. Behaviour and Information Technology, [online] 37(4), pp.311-319. Available at: $<$ https://doi.org/10.1080/0144929X.2018.143659 $0>$ [Accessed 26 Jul. 2020]. 